\title{
PENINGKATAN KETERAMPILAN BERKOMUNIKASI MELALUI MODEL PEMBELAJARAN KOOPERATIF JIGSAW
}

\author{
Sofiyana Rizki ${ }^{1)}$, Mawardi ${ }^{2)}$, dan Herlina Kasih Intan Permata ${ }^{3)}$ \\ Program Profesi Guru Sekolah Dasar, Universitas Kristen Satya Wacana \\ rizkisofiyana@gmail.com, mawardi@satff.uksw.edu
}

\begin{abstract}
The research was aimed to solve the problem of low students' communication skills in the learning process which applied Jigsaw cooperative learning model in the class five of Tingkir Lor 02 Elementary School Salatiga city. This method of research is Classroom Action Research used spiral model which referred to Kemis and Mc. Tagart' research design. This research procedure was done by implementing Jigsaw cooperative learning model which was planned by started from design arrangement, action, observation, and reflection. Data collection techniques in this study used observation and communication skills assessment rubic. The data analysis technique used is comparative descriptive technique between cycles. This classroom action research applied two cycles pattern. The conclusion of this research is the implementation of Jigsaw cooperative learning can improve students' communication skills. It can be seen from the increase of communication skills average score percentage from cycle I and cycle II that is 11,78\% with average score in cycle I is 75,5 increased into cycle II that is 84,4.

Keywords: Communication Skills, Jigsaw Model
\end{abstract}

\section{Abstrak}

Penelitian ini bertujuan untuk memecahkan masalah rendahnya keterampilan berkomunikasi peserta didik dalam pembelajaran dengan menerapkan model pembelajaran kooperatif Jigsaw di kelas 5 di SD Negeri Tingkir Lor 02 Kota Salatiga. Metode penelitian ini adalah Penelitian Tindakan Kelas menggunakan model spiral yang mengacu desain penelitian Kemmis dan Mc. Taggart. Prosedur penelitian ini dilaksankan dengan menerapkan model pembelajaran kooperatif Jigsaw yang direncanakan dimulai dari penyususnan rancangan, pelaksanaan tindakan, pengamatan (observasi), dan refleksi. Penelitian tindakan kelas ini menerapkan pola dua siklus. Teknik pengumpulan data menggunakan observasi dan rubrik penilaian keterampilan komunikasi. Teknik analisis data yang digunakan adalah teknik deskriptif komparatif antar siklus. Hasil penelitian ini yaitu penerapan model pembelajaran Kooperatif Jigsaw dapat meningkatkan keterampilan berkomunikasi peserta didik. Hal tersebut dapat dilihat dari kenaikan persentase skor rata-rata untuk ketererampilan berkomunikasi dari siklus I ke siklus II yaitu sebesar $11,78 \%$, dengan skor rata-rata pada siklus I yaitu 75,5 naik di siklus II menjadi 84,4 .

Kata Kunci: Keterampilan Berkomunikasi, Model Jigsaw

\section{PENDAHULUAN}

Komunikasi merupakan hal yang penting dalam proses pembelajaran. Akibat adanya komunikasi baik secara intrapersonal (berfikir, mengingat, dan melakukan persepsi) maupun secara interpersonal (penyaluran ide, menghargai pendapat, dan menyimak argumentasi) sangat berpengaruh terhadap proses pembelajaran. Dalam pembelajaran, kemampuan berkomunikasi menjadi syarat penting. Hal tersebut dikarenakan kemampuan berkomunikasi dapat membantu peserta didik mengutarakan gagasan serta bertukar informasi. Suasana pembelajaran yang aktif sangat didukung oleh keterampilan peserta didik dalam berkomunikasi. Peserta didik yang memiliki keterampilan berkomunikasi akan 
merasa percaya diri dalam mengungkapkan argumentasinya sehingga sangat berdampak pada suasana pembelajaran yang aktif.

Keterampilan berkomunikasi menjadi dimensi keterampilan yang penting dikuasai peserta didik terlebih dalam menghadapi abad ke-21. Pada abad ke-21 minimal ada empat kompetensi belajar yang harus dikuasai yakni kemampuan pemahaman yang tinggi, kemampuan berpikir kritis, kemampuan berkolaborasi dan berkomunikasi, serta kemampuan berpikir kritis. Dengan demikian komunikasi memainkan peranan yang amat penting dalam proses pembelajaran. Melalui kurikulum 2013, diharapkan dapat mengimplementasikan kompetensi pembelajaran abad ke-21. Hal tersebut berguna untuk menyikapi tuntutan zaman yang semakin kompetitif.

Dalam sebuah kesempatan melakukan diskusi dengan guru mitra, peneliti mendapatkan informasi bahwa dokumen kurikulum yang berlaku di SDN Tingkir Lor 02 adalah Kurikulum 2013. Sekolah tersebut sudah berusaha melaksanakan pembelajaran yang sesuai dengan tuntutan kurikulum. Guru kelas 5 SDN Tingkir Lor 02 ikut berkontribusi dengan menerapkan berbagai strategi pembelajaran agar tercipta proses pembelajaran yang menantang, menyenangkan, komunikatif, tanpa takut salah dan demokrasi. Usaha yang dilakukan guru kelas 5 tidak diimbangi dengan respon baik dari seluruh peserta didik. Ada beberapa peserta didik yang aktif dalam pembelajaran, sementara yang lain cenderung pasif. Peserta didik cenderung terlihat pasif ketika dimintai argumentasinya. Sikap yang ditunjukkan peserta didik saat diskusi antara lain kurang percaya diri karena merasa khawatir argumentasinya keliru dan bersikap masa bodoh karena sudah ada temannya yang menjawab pertanyaan. Hal tersebut menyebabkan peserta didik benar-benar tidak memahami materi yang disampaikan sehingga berdampak pada hasil belajar yang rendah.

Setelah dilakukan diskusi dan refleksi dengan guru kelas V, kondisi-kondisi seperti ini terjadi dikarenakan (1) kurangnya komunikasi yang terjalin dengan baik antara guru dengan peserta didik, atau diantara sesama peserta didik; (2) komunikasi yang terjalin cenderung satu arah, jadi terlihat hanya guru saja yang aktif; (3) kelas di dominasi oleh beberapa peserta didik yang aktif; (4) keterampilan berkomunikasi dalam mempresentasikan hasil diskusi di depan kelas atau di papan display masih terlihat malu dan ragu; serta (5) rendahnya aktivitas peserta didik dalam pembelajaran berdampak pada potensi berpikir tidak berkembang secara optimal yang dibuktikan dengan data prasiklus yang menunjukkan bahwa hasil pembelajaran tematik peserta didik kelas $\mathrm{V}$ dari jumlah 31 peserta didik, hanya 42\% (13 peserta didik) yang mendapat nilai di atas Kriteria Ketuntasan Minimal (KKM), sementara 58\% (18 peserta didik) lainnya mendapat nilai di bawah KKM.

Berkaitan permasalahan yang telah diuraikan, peneliti berkolaborasi dengan guru kelas $\mathrm{V}$ mencari solusi untuk pemecahan masalah. Solusi yang diperlukan yaitu penerapan teknik pembelajaran yang dapat menggali kemampuan komunikasi peserta didik. Salah satu model pembelajaran yang dapat meningkatkan keterampilan berkomunikasi peserta didik adalah model pembelajaran kooperatif tipe Jigsaw. Hal ini senada dengan (Vanalita, M., Jalmo, T., 2014) yang memaparkan bahwa keterampilan berkomunikasi dapat dikembangkan dan dimunculkan melalui aktifitas pembelajaran yang dikendalikan oleh guru melalui model pembelajaran kooperatif Jigsaw. 
Selain peningkatan keterampilan berkomunikasi, model kooperatif Jigsaw juga dapat meningkatkan keterampilan komunikasi interpersonal seperti yang dipaparkan oleh (Illa, Suryaningsih dan Nursalim, 2017) serta (Santoso,A.P, Goeritno, Haryo dan Utami, 2015). Hal ini akan menjadi pengalaman belajar bagi peserta didik yang dapat diterapkan dalam kehidupan bermasyarakat.

Penelitian yang dilakukan oleh (Marfungah, 2017)merupakan penelitian yang relevan dengan penelitian ini. Hasil penelitian menunjukkan bahwa ada peningkatan keterampilan komunikasi yang signifikan setelah dilakukan tindakan sebanyak tiga siklus. Perbedaan penelitian yang telah dilaksanakan oleh Marfuah (2017) dengan penelitian ini terletak pada subjek penelitiannya yaitu siswa SMP IT Al Qalam Depok, sementara pada penelitian ini subjek penelitiannya yaitu siswa SDN Tingkir Lor 02. Penelitian lain yang relevan dengan penelitian ini adalah penelitian yang dilakukan oleh Yusmaheri dengan hasil penelitian berupa peningkatan keaktifan dan hasil belajar siswa dengan menggunakan model Jigsaw. Hal tersebut menunjukkan adanya perbedaan dengan penelitian ini yaitu penelitian tersebut berfokus pada keaktifan dan hasil belajar siswa, sedangkan pada penelitian ini berfokus pada keterampilan berkomunikasi.

Adapun penelitian yang dilakukan oleh (Aeni, Annisa Aul, Arianto,J., 2017) yang dilakukan pada siswa kelas XI IPA SMAN 3 Boyolali menunjukkan bahwa penerapan model jigsaw dapat meningkatkan keterampilan berkomunikasi. Selain itu terdapat juga penelitian lain yang relevan dengan penelitain ini, yaitu penelitian yang dilakukan oleh (Yoshida, 2018) yang menunjukkan bahwa model jigsaw dapat diterapkan untuk memperluas komunikasi antar mahasiswa di univeristas Chiba Jepang. Hal tersebut menunjukkan bahwa terdapat perbedaan berupa subjek penelitian yang digunakan dalam penelitian. Pada penelitian ini, peneliti menggunakan subjek penelitian berupa siswa SDN Tingkir Lor 02.

Dari beberapa penelitian yang telah dilakukan, belum terdapat penelitian yang menerapkan model jigsaw untuk meningkatkan keterampilan komunikasi pada peserta didik di Sekolah Dasar. Kalaupun ada, penelitian yang dilakukan di SD seperti yang dilakukan oleh Bulan (2016) bahwa jigsaw dapat meningkatkan keterampilan berbicaranya saja belum mengadakan penelitian kemampuan berkomunikasi secara keselurahan.

Berdasarkan kondisi serta alternatif-alternatif yang telah dipaparkan, peneliti akan menerapkan model Jigsaw. (Isjoni., 2009) menjelaskan bahwa pembelajaran kooperatif Jigsaw merupakan model yang mendorong siswa aktif untuk saling membantu dalam menguasai materi pelajaran untuk mencapai prestasi yang maksimal. Senada dengan (Nurhaeni, 2011) mengungkapkan bahwa keterampilan komunikasi dapat meningkatkan dengan model Jigsaw dengan diskusi kelompok ahli dan kelompok asal serta meningkatkan pemahaman siswa terhadap materi. Berdasarkan penjabaran di atas, tujuan penelitian ini adalah meningkatkan keterampilan berkomunikasi siswa melalui model pembelajaran kooperatif Jigsaw kelas V SDN Tingkir Lor 02 Salatiga.

\section{METODE}

Penelitian tindakan kelas ini dilakukan mulai dari penyususnan rancangan, pelaksanaan tindakan, pengamatan (observasi), dan refleksi yang kemudian diikuti dengan siklus spiral berikutnya. (Wiriatmadja, 2014). Penelitian tindakan kelas ini apabila disiklus I belum memenuhi target atau tujuan yang diharapkan, maka 
dilakukan perbaikan pada siklus selanjutnya melalui analisis masalah dan refleksi tindakan. Subjek penelitian tindakan kelas ini adalah peserta didik kelas V SDN Tingkir Lor 02 semester II tahun pelajaran 2018/2019 dengan jumlah peserta didik dalam satu kelas ada 31 peserta didik terdiri dari 12 berjenis kelamin laki-laki dan 19 berjenis kelamin perempuan.

Teknik pengumpulan data dalam penelitian ini yaitu teknik non tes. Pada penelitian ini, teknik non tes yang digunakan oleh peneliti berupa rubrik penilain untuk mengukur keterampilan berkomunikasi peserta didik kelas V SDN Tingkir Lor 02 pada tema 8 Lingkungan Sahabat Kita, setelah dilaksanakan tindakan oleh guru kelas dengan menggunakan model kooperatif jigsaw. Sementara untuk teknik non tes, peneliti menggunakan lembar observasi yang digunakan untuk mengamati proses pembelajaran dan mengetahui hambatan yang dihadapi peserta didik serta guru selama pembelajaran menerapkan model kooperatif jigsaw. Pada lembar observasi juga terdapat rubrik keterampilan yang digunakan untuk mengukur keterampilan berkomunikasi. yang akan diamati oleh observer dalam pelaksanaan model kooperatif jigsaw untuk meningkatkan keterampilan berkomunikasi. Selain lembar observasi peneliti juga menggunakan teknik non tes berupa dokumentasi yang bertujuan untuk memperkuat data yang diperoleh oleh observer selama kegiatan observasi berlangsung.

Analisis data dalam penelitian ini menggunakan teknik analisis deskriptif kualitatif dan analisis komparatif kuantitatif. Teknik analisis deskriptif kualitatif bertujuan menganalisis data-data hasil observasi aktivitas peserta didik dan guru selama pembelajaran dengan menerapkan model pembelajaran kooperatif Jigsaw. Adapun teknik analisis komparatif kuantitatif untuk mengukur keterampilan berkomunikasi siswa menggunakan persentase dan angka.

Penelitian ini dinyatakan berhasil jika aktivitas peserta didik serta guru dalam menerapkan model pembelajaran kooperatif Jigsaw masuk kategori baik dan peresentase kenaikan rata-rata untuk keterampilan berkomunikasi naik $\geq 10 \%$.

\section{HASIL DAN PEMBAHASAN}

Data yang akan dianalisis pada penelitian tindakan kelas ini, yaitu: (1) aktivitas peserta didik dan guru dalam melaksanakan pembelajaran tematik menerapkan model kooperatif jigsaw meningkat; (2) rata-rata untuk keterampilan berkomunikasi siswa dalam pembelajaran menerapkan model kooperatif Jigsaw pada siklus I dan siklus II. Hasil analisis kemudian disajikan secara analisis baik menggunakan deskriptif kualitatif dan analisis komparatif kuantitatif dengan membandingkan hasil pada siklus I dan siklus II.

Kondisi awal penelitian ini dilakukan dengan melaksanakan observasi pelaksanaan pembelajaran tematik pada kelas V SD Negeri Tingkir Lor 02, dengan mendapatkan masalah untuk peserta didik kelas V SDN Tingkir Lor 02 dalam keterampilan berkomunikasi masih tergolong rendah bahkan ada peserta didik yang tergolong sangat rendah. Peserta didik pasif ketika dimintai argumentasinya. Sikap yang ditunjukkan saat diskusi antara lain kurang percaya diri karena merasa khawatir argumentasinya keliru, bersikap masa bodoh karena sudah ada temannya yang menjawab pertanyaan, hingga akhirnya peserta didik benar-benar tidak memahami materi yang berakibat hasil belajar menjadi rendah.Selanjutnya dilakukan Penelitian Tindakan Kelas yang berlangsung sebanyak 2 siklus. Hasil pelaksanaan tindakan pada siklus I dan II untuk 
keterampilan berkomunikasi siswa kelas V SDN Tingkir Lor 02 dapat dilihat dalam tabel berikut ini:

Tabel 1. Data Distribusi Frekuensi Keterampilan Berkomunikasi Siklus I dan Siklus II Siswa SDN Tingkir Lor 02

\begin{tabular}{clcccc}
\hline Interval & \multicolumn{1}{c}{ Kategori } & \multicolumn{2}{c}{ Siklus I } & \multicolumn{2}{c}{ Siklus II } \\
\hline & & Frekuensi & Persentase & Frekuensi & Persentase \\
\hline 81 & Sangat Tinggi & 15 & $48,39 \%$ & 26 & $83,87 \%$ \\
$61-80$ & Tinggi & 12 & $38,71 \%$ & 5 & $16,13 \%$ \\
$41-60$ & Cukup Tinggi & 4 & $12,90 \%$ & 0 & $0,00 \%$ \\
$21-40$ & Rendah & 0 & $0,00 \%$ & 0 & $0,00 \%$ \\
$\leq 20$ & Sangat Rendah & 0 & $0,00 \%$ & 0 & $0,00 \%$ \\
\hline & Jumlah & $\mathbf{3 1}$ & $\mathbf{1 0 0 , 0 0 \%}$ & $\mathbf{3 1}$ & $\mathbf{1 0 0 , 0 0 \%}$ \\
\hline
\end{tabular}

Berdasarkan tabel di atas data hasil penelitian tindakan berkaitan keterampilan berkomunikasi peserta didik pada pembelajaran siklus I diperoleh hasil yaitu dari 31 peserta didik terdapat 15 peserta didik $(48,39 \%)$ mencapai predikat "Sangat Tinggi", 12 siswa (38,71\%) dengan predikat "Tinggi", dan 4 peserta didik $(12,90 \%)$ dengan predikat "Cukup Tinggi". Sedangkan pada pembelajaran siklus II diperoleh hasil yaitu sebanyak 26 peserta didik $(83,87 \%)$ mencapai predikat "Sangat Tinggi", 5 peserta didik (16,13\%) dengan predikat "Tinggi", dan sudah tiadak ada peserta didik yang mendapatkan kategori cukup.

Adapun perbedaan yang terjadi pada siklus II dibanding siklus I yaitu sudah tidak terlihat peserta didik dengan predikat "Cukup Tinggi". Hal ini menunjukkan terjadi peningkatan cukup signifikan untuk keterampilan berkomunikasi peserta didik. Hal ini menunjukkan pemaparan (Vanalita, M., Jalmo, T., 2014), (Marfungah, 2017)dan (Gaffar, 2017) keterampilan berkomunikasi dapat ditingkatkan dengan model Jigsaw.

Berdasarkan data yang disajikan dalam tabel 1 menunjukkan keterampilan berkomunikasi peserta didik dalam pembelajaran tematik menggunakan model pembelajaran kooperatif jigsaw mengalami perubahan yang signifikan antara siklus I ke siklus II. Dari tabel 1 dapat disajikan ke dalam bentuk grafik berikut:

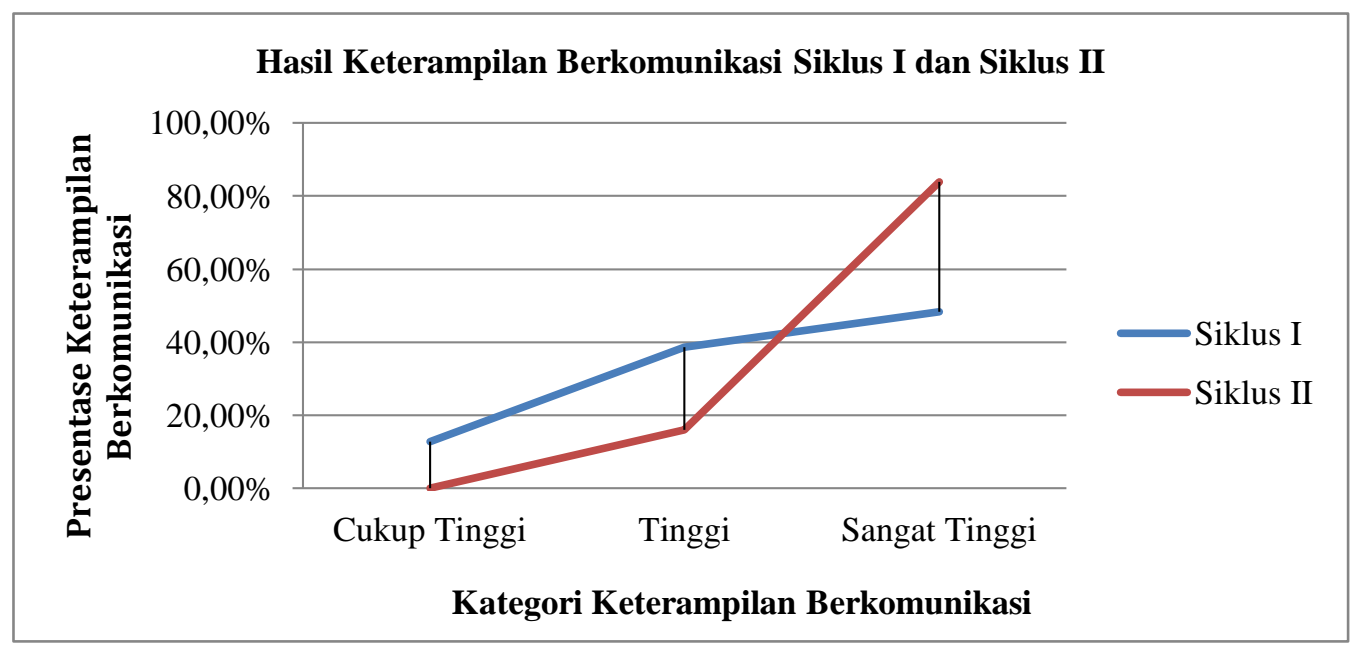

Gambar 1. Grafik Hasil Keterampilan Berkomunikasi Siklus I dan Siklus II

Dari grafik hasil keterampilan berkomunikasi pada siklus I ada 4 peserta didik dengan persentase yang didapat ada 12,90\% mendapat kategori "Cukup Tinggi". Setelah diadakan siklus ke II ada 4 peserta didik mampu mencapai indikator dan mendapatkan predikat "Tinggi" sehingga pada siklus II siswa yang mendapatkan 
predikat "Tinggi" mencapai 5 peserta didik, 4 siswa dari siklus I yang mendapat kategori "Cukup Tinggi" dan 1 peserta didik pada siklus I memang belum mencapai kenaikan pada siklus II untuk mendapatkan kategori "Sangat Tinggi".

Selain data hasil distribusi frekuensi keterampilan berkomunikasi, dalam penelitian ini diperoleh data analisis komparatif kuantitatif untuk perbandingan rata-rata, skor tertinggi dan skor terendah keterampilan berkomunikasi. Berikut tabel perbandingan rata-rata, skor tertinggi dan skor terendah keterampilan berkomunikasi yang di dapat siswa pada siklus I maupun siklus II:

Tabel 2. Perbandingan Rata-Rata, Skor Tertinggi dan Skor Terendah Keterampilan Berkomunikasi pada Siklus I dan Siklus II

\begin{tabular}{cccc}
\hline Siklus & Rata-rata & Nilai Tertinggi & Nilai Terendah \\
\hline I & 75,5 & 88 & 58 \\
\hline II & 84,4 & 92 & 71 \\
\hline
\end{tabular}

Pada tabel 2 disajikan keterampilan berkomunikasi siswa pada siklus I untuk rata-rata yaitu 75,5 untuk nilai tertinggi 88 dannilai terendah 58. Hasil siklus II menunjukkan rata-rata 84,4 untuk nilai tertinggi 92. Sedangkan nilai terendahnya adalah 71. Setelah dilaksanakan perbaikan pada siklus II untuk keterampilan berkomunikasi terlihat perubahan yang sangat signifikan skor rata-rata naik dengan adanya kenakan nilai tertinggi dan terendah peserta didik. Persentase kenaikan rata-rata keterampilan berkomunikasi pada siklus I dan siklus II dapat dilihat tabel berikut:

Tabel 3. Data Persentase Kenaikan Rata-Rata Keterampilan Berkomunikasi pada Siklus I dan Siklus II

\begin{tabular}{ccc}
\hline $\begin{array}{c}\text { Skor Rata-Rata } \\
\text { Siklus I }\end{array}$ & $\begin{array}{c}\text { Skor Rata-Rata } \\
\text { Siklus II }\end{array}$ & $\begin{array}{c}\text { Persentase Kenaikan } \\
\text { Siklus I dan Siklus II }\end{array}$ \\
\hline 75,5 & 84,4 & $11,78 \%$ \\
\hline
\end{tabular}

Berdasarkan data yang ada pada tabel 3 dari rata-rata siklus I sebesar 75,5 dan siklus II sebesar 84,4 dapat kita ketahui presentase kenaikan keterampilan berkomunikasi sisiwa sebesar $11,78 \%$ dan memenuhi indikator keberhasilan yang telah ditetapkan kenaikannya yaitu sebesar $\geq 10 \%$. Selain data peningkatan skor rata-rata keterampilan berkomunikasi mengalami kenaikan, dampak dari aktivitas guru dan peserta didik menggunakan model pembelajaran kooperatif Jigsaw peserta didik menjadi lebih aktif dalam pembelajaran baik aktif bertanya, berpendapat maupun menanggapi pendapat orang lain. Seperti penelitian yang dilakukan (Yusmaherni., 2018)menyatakan bahwa model Jigsaw dapat meningkatkan keaktifan peserta didik. Begitu juga (Widyastuti, 2017) juga sependapat bahwa melalui strategi pembelajaran Jigsaw, peserta didik akan berusaha untuk membangun pengetahuannya sehingga menuntutnya untuk terlibat aktif dalam proses diskusi di dalam kelompok. Keterlibatan peserta didik dalam proses diskusi menuntutnya untuk berkomunikasi.

Pada aktivitas peserta didik pembelajaran siklus I beberapa peserta didik belum berani menanyakan materi pembelajaran. Hal ini juga karena guru belum memberikan pertanyaan-pertanyaan dasar untuk menggali pengetahuan peserta didik, dan guru belum memberikan penguatan serta bimbingan pada kelompok secara merata. Kemudian pada siklus II dilaksanakan refleksi dan dilanjutkan tindakan, untuk aktivitas guru dan peserta didik dalam melakukan sintak model pembelajaran kooperatif Jigsaw sudah masuk kategori baik. Hal ini berdasarkan 
hasil observasi pelaksanaan pembelajaran dengan menerapkan model pembelajaran kooperatif Jigsaw terlihat guru memberikan peserta didik pertanyaan dasar apabila siswa ada yang belum paham terhadap kompetensi yang akan dicapai dalam pembelajaran, serta guru membimbing secara merata kepada siswa baik dalam kelompok asal maupun kelompok ahli. Peserta didik sudah aktif menanya baik antar peserta didik maupun kepada guru tanpa ragu dan peserta didik berani mengemukakan pendapatnya. Hal tersebut menunjukkan model Jigsaw juga meningkatkan keterampilan komunikasi khusunya komunikasi interpersonal seperti pemaparan (Illa, Suryaningsih dan Nursalim, 2017) serta (Santoso,A.P, Goeritno, Haryo dan Utami, 2015)

\section{SIMPULAN}

Berdasarkan hasil penelitian dan pembahasan, dapat diketahui bahwa model pembelajaran Koopertif Jigsaw dapat meningkatkan keterampilan berkomunikasin peserta didik sehingga berpengaruh pada hasil belajar tematik kelas V SDN Tingkir Lor 02 Salatiga apabila langkah-langkah pembelajaran dengan model Koopertif Jigsaw masuk kategori baik. Hal ini ditunjukkan pada siklus I sampai siklus II aktivitas guru dan peserta didik dalam menerapkan model pembelajaran Koopertif Jigsaw memperoleh kategori baik dan sangat baik. Selain itu, penerapan model pembelajaran kooperatif Jigsaw pada siswa kelas V SD Negeri Tingkir Lor 02 Tahun Ajaran 2018/2019 diketahui memenuhi indikator keberhasilan yang telah ditetapkan dan untuk tingkat ketuntasan belajar tematik peserta didik juga mengalami peningkatan. Berdasarkan uraian di atas dapat disimpulkan bahwa penerapan model pembelajaran kooperatif Jigsaw dapat meningkatkan keterampilan berkomunikasi dan hasil belajar peserta didik.

\section{DAFTAR RUJUKAN}

Aeni, Annisa Aul, Arianto,J., dan S. S. (2017). Studi Komparasi Capaian Keterampilan Komunikasi Siswa Antara Penerapan Model Kooperatif Tipe Jigsaw Disertai Praktikum dengan Model Guided Discovery pada Siswa Kelas XI IPA SMAN 3 Boyolali Tahun Ajaran 2016/2017. In Proceeding Biology Education Conference 2 (14) (pp. 340-346).

Gaffar, A. A. (2017). Penerapan Model Jigsaw untuk Meningkatkan Keterampilan Berkomunikasi Siswa pada Materi Sistem Peredaran Darah Pada Manusia. Jurnal Bio Edicatio, 2(2), 21-26.

Illa, Suryaningsih dan Nursalim, M. (2017). Penerapan Teknik Jigsaw Dalam Layanan Informasi Untuk Meningkatkan Kemampuan Komunikasi Interpersonal Siswa KELAS XI TEI 3 SMKN I Driyorejo. Gresik: Universitas Negeri Surabaya.

Isjoni. (2009). Pembelajaran Kooperatif Meningkatkan Kecerdasan Komunikasi antar Peserta Didik. Yogyakarta: Pustaka Pelajar.

Marfungah. (2017). Meningkatkan Keterampilan Komunikasi Peserta Didik melalui Model pembelajaran Kooperatif Tipe Jigsaw. Jurnal Pendidikan Ilmu Sosial (JPIS), 26(2), 148-160. 
Nurhaeni, Y. (2011). Meningkatkan Pemahaman Siswa Pada Konsep Listrik Melalui Pembelajaran Kooperatif Jigsaw Pada Siswa Kelas IX SMPN 43. Bandung.

Santoso,A.P, Goeritno, Haryo dan Utami, C. T. (2015). Efektivitas Model Pembelajaran Kooperatif Jigsaw Untuk Meningkatkan Komunikasi Interpersonal Pada Mahasiswa Psikologi. Prediksi, Kajian Ilmiah Psikologi, $4(1), 1-10$.

Vanalita, M., Jalmo, T., \& M. (2014). Pengaruh Model Pembelajaran Jigsaw terhadap Kemampuan Komunikasi Lisan dan Hasil Belajar Siswa. Bandar Lampung: Universitas Lampung.

Widyastuti, D. W. (2017). Strategi Dalam Mengembangkan Keterampilan Komunikasi Interpersonal Calon Konselor,. In Proseding FKIP UAD P-05 (pp. 26-32). Yogyakarta.

Wiriatmadja, R. (2014). Metode Penelitian Tindakan Kelas. Bandung: Remaja Rosdakarya. Yusmaherni. (2018). Meningkatkan Aktifitas Belajar Matematika Mate.

Yoshida, M. (2018). A Teaching Method that Promotes Scholarly Communication Communication Jigsaw: A Teaching Method that Promotes Scholarly Communication. International Journal of Emerging Technologies in Learning (IJET), 13(10), 208-224.

Yusmaherni. (2018). Meningkatkan Aktifitas Belajar Matematika Materi Pecahan Dengan Menggunakan Model Kooperatif Tipe Jigsaw Pada Siswa Kelas IV SDN NO. 101/II Muara Bungo Kec. Pasar Muara Bungo Kab. Bungo. Jurnal Bidang Pendidikan Dasar (JBPD), 2(IA), 23-34. 